\title{
EFFECTS OF NICOTINIC ACID ON PROTEIN OXIDATIVE MODIFICATIONS IN EXPERIMENTAL CHRONIC HEART FAILURE
}

\author{
IRYNA NIZHENKOVSKA, VIOLETTA NAROKHA*, OLENA KUZNETSOVA \\ Bogomolets National Medical University, Department of Pharmaceutical, Biological and Toxicological Chemistry, \\ Pushkinska str., 22, 01601, Kyiv, Ukraine
}

*corresponding author:v.narokha@ukr.net

Manuscript received: September 2016

\begin{abstract}
A model of chronic heart failure experimental model was induced to rats based on the toxic effects of doxorubicin. The nature of changes in the content of protein peroxidation products (neutral and basic 2,4-dinitrophenylhydrazones) was established in cardiomyocytes and hepatocytes of rats which received weekly intramuscular doxorubicin for 5 weeks in a dose of $5 \mathrm{mg} / \mathrm{kg}$ body weight (bw) together with the daily intraperitoneal administration of nicotinic acid, $10 \mathrm{mg} / \mathrm{kg} \mathrm{bw}$. The obtained results pointed out reduced protein peroxidation in cardiomyocytes caused by nicotinic acid, in a chronic heart failure model in rats. This allows to consider nicotinic acid as a drug with a potential cardioprotective activity.

\section{Rezumat}

Insuficiența cardiacă cronică a fost indusă la șobolani într-un model experimental bazat pe efectele toxice ale doxorubicinei. S-a evaluat natura modificărilor produşilor de peroxidare proteică (2,4-dinitrofenilhidrazone neutre şi bazice) de la nivelul cardiomiocitelor și hepatocitelor la șobolani cărora li s-a administrat doxorubicină intramuscular săptămânal, timp de 5 săptămâni, într-o doză de $5 \mathrm{mg} / \mathrm{kg}$ corp, concomitent cu administrarea zilnică intraperitoneală de acid nicotinic, $10 \mathrm{mg} / \mathrm{kg}$ corp. Rezultatele obținute arată o peroxidare proteică redusă în cardiomiocite animalelor cu insuficiență cardiacă cronică, datorată acidului nicotinic. Aceste rezultate permit luarea în considerare a acidului nicotinic ca medicament cu potențială activitate cardioprotectoare.
\end{abstract}

Keywords: niacin, protein oxidation, oxidative stress, chronic heart failure, doxorubicin

\section{Introduction}

Studies of protein oxidative modifications are performed due to important the role of proteins in the cell and the whole body. Quantitatively, proteins prevail over all other macromolecules in the living cell and are involved in all biological processes, performing various functions. In addition, proteins are more susceptible to free radical oxidation compared to other biomolecules and their oxidation is the earliest stable indicator of the intensity of the generation of active oxygen species that can be mediators of cell damage in cardiovascular diseases, such as ischemia, atherosclerosis and hypertension [1-5].

Studies of the protein degradation pathways which trigger the onset of pathological processes in the organism will contribute to the understanding of the mechanisms of the most common human diseases, one of which is chronic heart failure. These will generate new approaches to the development of drugs for the treatment and prevention of cardiovascular diseases.

Niacin has been used in the treatment of cardiovascular disease, although its use has largely been superseded by better-tolerated lipid-modulating therapies [6-9]. The antioxidant effects of niacin, administered to rats in doses of $10 \mathrm{mg} / \mathrm{kg} \mathrm{bw}$ in a doxorubicin-induced chronic heart failure model, presented our previous publications, are normalization of redox process in the myocardium through inhibition of reactive oxygen species namely, superoxide anion radical and hydrogen peroxide, as well as oxidation of polyunsaturated fatty acids $[10,11]$. The purpose of this study is to investigate protein oxidative modifications in cardiomyocytes and hepatocytes under the influence of nicotinic acid in a rat experimental model of chronic heart failure.

\section{Materials and Methods}

The studies were conducted on adult male Wistar rats $(180-220 \mathrm{~g})$. All procedures and experimental protocols involving animals were in compliance with the European Community guidelines (2010/63/EU) [12], as well as the provisions of the General Ethical Principles of Animal Experiments approved by the $1^{\text {st }}$ National Congress on Bioethics (Kyiv, 2001) and the Law of Ukraine No. 3447-IV On the Protection of Animals from Cruelty. The animals were fed a normal, balanced diet and had free access to water in the animal house (vivarium) of the Bogomolets National Medical University (Kyiv City, Ukraine). 
FARMACIA, 2018, Vol. 66, 6

Doxorubicin-KMP in the form of a $0.01 \mathrm{~g}$ lyophilized powder for the solution for injection (Kyivmedpreparat, OJSC, Ukraine) and nicotinic acid (niacin) BP, crystalline powder (Aarti Drugs Ltd, India) were used in the study.

The animals were randomly divided into 3 groups (10 animals in each group): $1^{\text {st }}$ group: animals that received weekly intramuscular injections of normal saline for 5 weeks (control); $2^{\text {nd }}$ group: experimental model of chronic heart failure: animals that received weekly intramuscular injections of doxorubicin $5 \mathrm{mg} /$ $\mathrm{kg}$ bw for 5 weeks (experimental chronic heart failure) [11]; $3^{\text {rd }}$ group: animals that received weekly intramuscular injections of doxorubicin $5 \mathrm{mg} / \mathrm{kg}$ bw for 5 weeks together with a daily intraperitoneal injection of nicotinic acid $10 \mathrm{mg} / \mathrm{kg}$ bw (experimental chronic heart failure + niacin).

Heart or liver tissues were placed in $0.25 \mathrm{M}$ sucrose solution at a ratio of $1 / 10(\mathrm{~m} / \mathrm{V})$ and were homogenized for 35 seconds at $900 \mathrm{rpm}$ in the Potter $\mathrm{S}$ homogenizer at a temperature not exceeding $4^{\circ} \mathrm{C}$. The homogenate was centrifuged for $10 \mathrm{~min}$ at $1,000 \mathrm{~g}$ for the deposition of incompletely destroyed cells and nuclei. The supernatant was centrifuged for 15 minutes at $14,000 \mathrm{~g}$ to remove mitochondria and then the resulting supernatant was centrifuged additionally at 20,000 g for 30 minutes to obtain clear cytoplasmic (nonsedimentary) fractions in which protein oxidative modifications were determined.

To evaluate the intensity of spontaneous protein oxidative modifications in cardiomyocytes and hepatocytes, a method modified by Dubinin et al. based on the reaction of carbonyl derivatives of proteins and Schiff bases with 2,4-dinitrophenylhydrazine to form 2,4-dinitrophenylhydrazones of neutral and basic nature was used [13]. An aliquot

of the test sample was placed in a tube containing $0.15 \mathrm{M}$ potassium phosphate buffer $(\mathrm{pH}=7.4)$. Proteins were precipitated by the addition of $20 \%$ trichloroacetic (TCA) solution. An equal volume $(1.0 \mathrm{~mL})$ of $0.1 \mathrm{M}$ solution of 2,4- dinitrophenylhydrazine in $2 \mathrm{M}$ $\mathrm{HCl}$ solution was added to denatured proteins. The control sample contained appropriate quantities of $2 \mathrm{M}$ $\mathrm{HCl}$ instead of 2,4-dinitrophenylhydrazine. The samples were incubated for 1 hour at room temperature. To isolate proteins, samples were centrifuged at $3000 \mathrm{~g}$ for $15 \mathrm{~min}$. The precipitate was washed three times with ethanol-ethyl acetate $(1: 1 \mathrm{v} / \mathrm{v})$ in order to remove lipids and oxidized proteins and was air dried. The dried precipitate was dissolved in $8 \mathrm{M}$ urea solution. The optical density of the resulting 2,4-dinitrophenylhydrazones was detected at wavelengths of $356 \mathrm{~nm}$ and $370 \mathrm{~nm}$ (aldehyde and ketone products of the neutral oxidative modification) and at $430 \mathrm{~nm}$ and $530 \mathrm{~nm}$ (aldehyde and ketone products of the basic oxidative modification) on a SF-26 spectrophotometer. The results were expressed in optical density units per $1 \mathrm{mg}$ of protein and were determined by the Lowry method [14].

Statistical analyses

Significance of differences between experimental and control groups was evaluated by Student's t-test. We regarded the differences as statistically significant at $\mathrm{p}<0.05$.

\section{Results and Discussion}

The study showed that the content of neutral aliphatic aldehyde and ketone dinitrophenylhydrazones, registered at 356 and $370 \mathrm{~nm}$, was higher than the content of basic aldehyde and ketone dinitrophenylhydrazones, registered at 430 and $530 \mathrm{~nm}$ (Table I).

Table I

Effects of niacin on protein oxidation in myocardium in rats with experimental chronic heart failure $(\mathrm{n}=10)$

\begin{tabular}{|c|c|c|c|c|}
\hline \multirow{2}{*}{ Animal groups } & \multicolumn{2}{|c|}{ Neutral products, optical units/mg of protein } & \multicolumn{2}{c|}{ Basic products, optical units/mg of protein } \\
\cline { 2 - 4 } & $356 \mathrm{~m}$ & $370 \mathrm{~nm}$ & $430 \mathrm{~nm}$ & $530 \mathrm{~nm}$ \\
\hline Control (Group 1) & $0.65 \pm 0.04$ & $0.44 \pm 0.04$ & $0.32 \pm 0.03$ & $0.23 \pm 0.02$ \\
\hline $\begin{array}{c}\text { Experimental chronic heart } \\
\text { failure (Group 2) }\end{array}$ & $0.67 \pm 0.06$ & $0.85 \pm 0.07^{*}$ & $0.74 \pm 0.06^{*}$ & $0.54 \pm 0.05^{*}$ \\
\hline $\begin{array}{c}\text { Experimental chronic heart } \\
\text { failure + niacin (Group 3) }\end{array}$ & $0.66 \pm 0.05$ & $0.68 \pm 0.05^{*}, \#$ & $0.56 \pm 0.04^{*}, \#$ & $0.39 \pm 0.03^{*}$,\# \\
\hline
\end{tabular}

Results are expressed as mean \pm standard deviation, ${ }^{*} \mathrm{p}<0.05$ compared to the control group, ${ }^{\#} \mathrm{p}<0.05$ compared to the group with experimental chronic heart failure

These results show that the secondary markers of oxidative stress prevail in the control group - neutral dinitrophenylhydrazones. The levels of aldehyde dinitrophenylhydrazones in cardiomyocytes in the control animals were higher than those of keto dinitrophenylhydrazones which may indicate a process of protein fragmentation to form low molecular weight fragments.

As a result of the study, we found a statistically significant increase in the basic aliphatic aldehyde and ketone dinitrophenylhydrazones in cardiomyocytes of the animals with experimental heart failure. Levels of basic aliphatic aldehyde and ketone dinitrophenylhydrazones in the cardiocytes of the animals with experimental heart failure were 2.3 times higher compared to the control group. This shows that the formation of proteins derived from carbonylhydrates induced by doxorubicin is mainly due to the oxidation of the amino acid residues having basic properties. The content of neutral aliphatic ketone dinitrophenyl- 
hydrazones in cardiocytes of the animals from group 2 was also significantly increased compared to the control group of animals. Therefore, data on the accumulation of aliphatic ketone dinitrophenylhydrazones in the cardiocytes of the animals from group 2 may indicate the presence of protein aggregation processes. No significant changes in the content of neutral aliphatic aldehyde-dinitrophenylhydrazones in the cardiomyocytes of the animals with experimental protein oxidative modifications compared to the control animals were registered.
The administration of nicotinic acid caused a statistically significant reduction in the content of dinitrophenylhydrazones determined at wavelengths of 370,430 and $530 \mathrm{~nm}$ when compared to group 2 of animals. Values of neutral aliphatic aldehyde dinitrophenylhydrazones in the cardiomyocytes did not differ in all treatment groups. The predominance of aliphatic aldehyde dinitrophenylhydrazones in cardiomyocytes suggests that oxidative stress does not reach its developmental stage and appears to be reversible.

Effects of niacin on protein oxidation in hepatocites in rats with experimental chronic heart failure $(\mathrm{n}=10)$

\begin{tabular}{|c|c|c|c|c|}
\hline Animal group & Neutral products, optical units/mg of protein & Neutral products, optical units/mg of protein \\
\cline { 2 - 4 } & $356 \mathrm{~nm}$ & $370 \mathrm{~nm}$ & $430 \mathrm{~nm}$ & $530 \mathrm{~nm}$ \\
\hline Control (Group 1) & $0.92 \pm 0.08$ & $1.06 \pm 0.09$ & $0.84 \pm 0.07$ & $0.92 \pm 0.08$ \\
\hline $\begin{array}{c}\text { Experimental chronic heart } \\
\text { failure (Group 2) }\end{array}$ & $1.49 \pm 0.13^{*}$ & $1.75 \pm 0.14^{*}$ & $1.46 \pm 0.11^{*}$ & $2.13 \pm 0.16^{*}$ \\
\hline $\begin{array}{c}\text { Experimental chronic heart } \\
\text { failure + niacin (Group 3) }\end{array}$ & $1.25 \pm 0.11^{*}$ & $1.52 \pm 0.11^{*}$ & $1.27 \pm 0.11^{*}$ & $1.84 \pm 0.17^{*}$ \\
Results are expressed as mean \pm standard deviation, ${ }^{*} \mathrm{p}<0.05$ compared to the control group
\end{tabular}

In the experimental conditions, of induced chronic heart failure, in rat hepatocytes (Table II) the increase to different extents in the content of neutral and basic aliphatic aldehyde and ketone dinitrophenylhydrazones was observed when compared to the group of control animals. This fact indicates an increase in the intensity of the oxidized protein degradation under doxorubicininduced oxidative stress and suggests that the doxorubicin targets in hepatocytes are both basic and neutral amino acid residues.

The fact that ketone dinitrophenylhydrazones are superior to aldehyde dinitrophenylhydrazones indicates that oxidative stress has reached its irreversible stage. The administration of nicotinic acid in the presence of doxorubicin acid did not result in a statistically significant reduction in the content of dinitrophenylhydrazones in animal hepatocytes measured at wavelengths of 356, 370, 430 and $530 \mathrm{~nm}$ when compared to group 2 of animals, whilst we observed a decrease in the intensity of oxidative stress in cardiomyocytes after nicotinic acid administration in the experimental chronic heart failure model used.

The parameters of the studied protein oxidative modifications products in rat hepatocytes from group 3 were significantly different from the values of the control group.

These data indicate a deep oxidative damage to proteins in the hepatocytes in this experimental model. The prevalence of secondary markers of oxidative stress, aliphatic ketone dinitrophenylhydrazones, in animal hepatocytes from group 3 indicates the active transition of the primary markers of oxidative stress to the secondary ones and aggravation of doxorubicininduced oxidation processes. These significant changes in the levels of basic ketone dinitrophenylhydrazones induced by doxorubicin are due to the protein glycosylation which is a typical marker of stress. It was shown that protein glycosylation was closely connected with free-radical processes and the content of the products of protein non-enzymatic glycosylation in oxidative stress was increased.

\section{Conclusions}

In the context of experimentally induced CHF with doxorubicin, deep oxidative damage to proteins is observed in cardiomyocytes and hepatocytes in experimental animals. The administration of nicotinic acid in animals with experimental heart failure significantly reduced the intensity of protein oxidative modification in cardiomyocytes. The results suggest that further studies of nicotinic acid and its derivatives as drugs reducing cardiotoxic effects of doxorubicin are necessary.

\section{References}

1. Dunlop RA, Brunk UT, Rodgers KJ, Oxidized proteins: mechanisms of removal and consequences of accumulation. International Union of Biochemistry and Molecular Biology, 2009; 61(5): 522-527.

2. Stadtman ER, Levine RL, Free radical-mediated oxidation of free amino acids and amino acid residues in protein. Amino Acids, 2003; 25(3-4): 207-218.

3. Stadtman ER, Levine RL, Protein oxidation. Ann $N$ Y Acad Sci., 2000; 899: 191-208.

4. Sugamura K, F.Keaney J, Reactive oxygen species in cardiovascular disease. Free Radical Biology and Medicine, 2011; 51(5): 978-992.

5. Uchida K, Role of reactive aldehyde in cardiovascular diseases. Free Radical Biology and Medicine, 2000; 28(12): 1685-1696.

6. Digby J, Ruparelia N, Choudhury R, Niacin in cardiovascular disease: recent preclinical and clinical 
developments. Arterioscler Thromb Vasc Biol., 2012; 32(3): 582-588.

7. Hochholzer W, Berg D, Giugliano R, The facts behind niacin. Ther Adv Cardiovasc Dis., 2011; 5(5):227-240.

8. Ganji SH, Qin S, Zhang L, Kamanna VS, Kashyap ML, Niacin inhibits vascular oxidative stress, redoxsensitive genes, and monocyte adhesion to human aortic endothelial cells. Atherosclerosis, 2009; 202(1): 68-75.

9. Yanhong Si, Ying Zhang, Jilong Zhao, Shoudong Guo, Lei Zhai, Shutong Yao, Hui Sang, Nana Yang, Guohua Song, Jue Gu, Shucun Q, Niacin inhibits vascular inflammation via downregulating nuclear transcription factor- $\kappa \mathrm{B}$ signaling pathway. Mediators Inflamm., 2014; 2014: 1-12.

10. Nizhenkovskaya IV, Narokha VP, Kuznetsova OV, Antioxidant effect of nicotinic acid on experimental doxorubicin-induced chronic heart failure in rats. Current Topics in Pharmacology, 2014; 18: 105-111.
11. Nizhenkovskaya IV, Narokha VP, Kuznetsova OV, Bryzgina TS, Seifullina II, Martsinko EE, Effects of nicotinic acid and complex of germanium with nicotinic acid (MIGU-1) on lipid fatty acid composition of cardiomyocytes and hepatocytes in rats with experimental chronic heart failure. Pharmacology and Drug Toxicology, 2015; 1(42): 68-75.

12. European directive $2010 / 63 / \mathrm{EU}$, available at: https://eur-lex.europa.eu.

13. Dubinin EE, Burmistrov SO, Moves DA, Porotov G, Oxidative modification of proteins in human serum, the method of its determination. Questions of medical chemistry, 1995. 41(1): 24-26.

14. Lowry OH, Rosebrough NJ, Farr AL, Randall RJ, Protein measurement with the Folin phenol reagent. J Biol Chem., 1951; 193: 265-275. 